\title{
Dietary Guidelines should reflect new understandings about adult protein needs Donald K Layman
}

Address: Department of Food Science \& Human Nutrition, University of Illinois, Urbana, IL 61801, USA

Email: Donald K Layman - dlayman@illinois.edu

Published: 13 March 2009

Nutrition \& Metabolism 2009, 6:12 doi:10.1186/1743-7075-6-12
Received: II February 2009

Accepted: 13 March 2009

This article is available from: http://www.nutritionandmetabolism.com/content/6/1/12

(C) 2009 Layman; licensee BioMed Central Ltd.

This is an Open Access article distributed under the terms of the Creative Commons Attribution License (http://creativecommons.org/licenses/by/2.0), which permits unrestricted use, distribution, and reproduction in any medium, provided the original work is properly cited.

\begin{abstract}
Dietary Guidelines for Americans provide nutrition advice aimed at promoting healthy dietary choices for life-long health and reducing risk of chronic diseases. With the advancing age of the population, the 2010 Dietary Guidelines confront increasing risks for age-related problems of obesity, osteoporosis, type 2 diabetes, Metabolic Syndrome, heart disease, and sarcopenia. New research demonstrates that the meal distribution and amount of protein are important in maintaining body composition, bone health and glucose homeostasis. This editorial reviews the benefits of dietary protein for adult health, addresses omissions in current nutrition guidelines, and offers concepts for improving the Dietary Guidelines.
\end{abstract}

\section{New concepts about protein for the Dietary Guidelines \\ - Protein is a critical part of the adult diet}

- Protein needs are proportional to body weight; NOT energy intake

- Adult protein utilization is a function of intake at individual meals

- Most adults benefit from protein intakes above the minimum RDA

The developing controversy about Dietary Guidelines for protein stems from current perceptions that protein intakes above minimum requirements have no benefit and may pose long-term health risks. These beliefs are largely based on assumptions and extrapolations with little foundation in nutrition science. Diets with increased protein have now been shown to improve adult health with benefits for treatment or prevention of obesity, oste- oporosis, type 2 diabetes, Metabolic Syndrome, heart disease, and sarcopenia [1-4]. This editorial argues that we need Dietary Guidelines that recognize these benefits and emphasize the right amounts of protein at specific meals.

Current perceptions are that protein is an expensive nutrient with limitations in the food supply and are reinforced by outcome measures that are based on strict cost/benefit approaches to diet formulation. This concept stems from animal science goals to maximize growth with the least expensive foodstuff. Animal feeding protocols focus on providing cheap carbohydrates as the primary energy source and limiting dietary protein to a substrate role for building new proteins. These measures are based on the body's ability to capture dietary nitrogen as body protein. Such thinking translates easily to childhood nutrition where growth and nitrogen accumulation are simple outcome measurements to confirm adequate dietary protein to maintain growth within percentile standards. Even measures of protein quality are derived from growth (Protein Efficiency Ratio: PER) and nitrogen balance (Net Pro- 
tein Utilization: NPU) evaluated under conditions of limited protein intake [5]. With this history, dietary guidelines for protein evolved to provide only the minimum RDA.

During the past decade a growing body of research reveals that dietary protein intakes above the RDA are beneficial in maintaining muscle function and mobility [6] and in the treatment of diseases including obesity, osteoporosis, type 2 diabetes (T2DM), Metabolic Syndrome (MetS), heart disease, and sarcopenia [1-4]. The new research establishes health benefits and provides molecular evidence of numerous metabolic outcomes associated with protein intake or amino acid metabolism that are not reflected in the traditional measure of nitrogen balance. These outcomes include cell signaling via leucine $[7,8]$, satiety $[9,10]$, thermogenesis $[11]$, and glycemic control $[12,13]$. The dietary protein necessary to optimize each of these metabolic outcomes is not reflected in measures of nitrogen balance and is not represented within the current concept of the minimum RDA. So what is known and what is missing in current Dietary Guidelines?

\section{Current Status and Errors of Omission}

Criteria for protein requirements are based on providing the minimum essential amino acids (EAA) necessary as building blocks for new protein structures [5]. The fundamental philosophy underpinning the RDA is that once substrate requirements for EAA are met then the need for protein is satisfied. Extension of this philosophy implies that any additional amino acids beyond the minimum RDA are unnecessary and have no nutritional value.

This concept of substrate adequacy is evaluated by shortterm nitrogen retention. Titration of amino acids into the diet from protein-free to surfeit intakes produces an almost linear response in nitrogen balance from negative to positive. Nitrogen balance (i.e. intake $=$ excretion) is assumed to reflect an Estimated Average Requirement (EAR $\sim 0.66 \mathrm{~g} / \mathrm{kg} / \mathrm{d}$ )[14]. This EAR plus a safety factor is the current RDA $(0.8 \mathrm{~g} / \mathrm{kg} / \mathrm{d})$ defined as "the minimum daily needs for protein to maintain short-term nitrogen balance in healthy people with moderate physical activity" [14].

At the inflection point for nitrogen balance, plasma concentrations of EAA rise rapidly stimulating amino acid oxidation [5] and this is taken as confirmation that nitrogen balance provides a measure of protein efficiency. The increase in plasma amino acids is thought to represent saturation of substrate needs (i.e. charging of tRNAs) and any additional amino acids are degraded by oxidation to energy. Amino acid oxidation serves to confirm nitrogen balance as a measure of protein efficiency. Protein intakes above the inflection point in nitrogen balance or amino acid oxidation are considered to reflect inefficient utiliza- tion or even unnecessary waste. This is the cost/benefit concept where the minimum cost of dietary ingredients is balanced with the potential for changes in body size. The goal is the largest body size for the least cost. This concept is fundamentally flawed when applied to non-growing adults.

Another major flaw in the Dietary Guidelines is the failure to recognize that dietary protein needs are inversely proportional to energy intake [15]. Current guidelines present protein needs as a percentage of energy in proportion to carbohydrates and fats. For example, MyPyramid represents the macronutrient goals as 55\% of energy from carbohydrates, $30 \%$ from fats, and $15 \%$ from protein. At high energy intakes this balance of macronutrients is adequate. A $70 \mathrm{~kg}$ adult with energy intake of $2500 \mathrm{kcal} /$ day would achieve a daily intake of $93 \mathrm{~g}$ of protein which is safely above the minimum $\mathrm{RDA}$ requirement of $56 \mathrm{~g} /$ day (i.e. $0.8 \mathrm{~g} / \mathrm{kg}$ ). However, if energy intake is reduced for weight management or during aging recommending protein as a percentage of energy is a serious error and potentially harmful. During weight loss, total daily energy intake is often below $1400 \mathrm{kcal} /$ day. If the protein goal is represented as $15 \%$ of energy intake, daily protein intake is limiting at only $52 \mathrm{~g}$. Protein needs are a function of lean tissue mass and must increase as a percentage of low energy diets.

The Food and Nutrition Board recognized the potential for biological diversity and individual choice with the DRI for macronutrients and created an Acceptable Macronutrient Distribution Range (AMDR)(14). The AMDR for protein provides a minimum RDA intake of $0.8 \mathrm{~g} / \mathrm{kg}$ with a range up to at least $2.5 \mathrm{~g} / \mathrm{kg}$ without any identifiable Upper Limit risk. The AMDR range was unfortunately converted into percentage of energy intakes (10\% to $35 \%$ of energy) to be consistent with guidelines for carbohydrates and fat. While this provides consistency for presentation of nutrient guidelines, presenting protein as a percent of energy reduces the apparent significance of dietary protein to that of a minor energy source. This is a critical conceptual issue for Dietary Guidelines. Consumers must understand that absolute protein requirements (grams per day) relate to body weight and remain virtually constant across all energy intakes. If protein recommendations are maintained as an indirect relationship with energy intake $(10 \%$ to $35 \%$ of energy), then Dietary Guidelines must emphasize that protein needs increase by approximately $1 \%$ for every $100 \mathrm{kcal}$ decrease in energy intake below $2000 \mathrm{kcal} /$ day.

Another error of omission in the Dietary Guidelines relates to recognition that the efficiency of protein utilization decreases throughout adult life [6]. During aging, there is an increase in the requirement for EAA to produce a posi- 
tive response in muscle protein synthesis [16,17]. The need for total protein may not change, but the effectiveness of amino acids to stimulate muscle (and probably bone) protein metabolism decreases requiring either more total protein or greater nutrient density of EAA/total protein (i.e. protein quality). The change in efficiency of EAA use appears to be associated with the loss of anabolic drive for development of lean tissue [18]. During growth, the body has a high metabolic priority for structural development of muscle and bone driven by anabolic hormones including insulin, growth hormone, IGF-1 and steroid hormones. Further, physical activity has a positive effect on the efficiency of use of amino acids [19]. Muscle protein synthesis is stimulated by stretching and resistance activity. The converse is also true; a sedentary lifestyle reduces the efficiency of EAA use. After approximately age $30 \mathrm{y}$, the anabolic drive is lost; basal levels of hormones become largely ineffective in stimulating protein synthesis in structural tissues; and diet quality and physical activity become the limiting factors for maintaining optimal protein turnover for repair, remodeling, and recovery.

In summary, omissions in current understanding of dietary protein needs are that 1) nitrogen balance and amino acid oxidation are only useful for defining minimum protein requirements and not optimum amino acid needs, 2) protein requirement is proportional to body weight and inversely proportional to energy intake, and 3) adults need more EAA than children to maintain the efficiency of protein turnover in structural tissues.

\section{New knowledge about protein}

Protein and amino acids contribute to multiple metabolic roles beyond simple substrates for protein synthesis. Die- tary protein influences cell signaling, satiety, thermogenesis and glycemic regulations and each of these roles is initiated by increases in plasma and intracellular amino acid concentrations. These metabolic outcomes only become important with intakes above the minimum RDA. Using current measures of nitrogen balance and amino acid oxidation as the only criteria for protein requirements, these metabolic outcomes are rejected outof-hand as inefficient and wasteful. A more logical view is that these new metabolic outcomes provide the basis for the AMDR and provide for individualization of dietary choice. Individuals can design healthy and adequate diets around the minimum RDA to prevent deficiency or design diets around higher levels of protein with additional health benefits.

Mechanisms for these metabolic outcomes are being unraveled and the effects appear to relate to the protein at each meal $[20,21]$. Current dietary guidelines focused on the RDA minimize the importance of protein as a central part of every meal and produce meal patterns with over $65 \%$ of protein consumed in a single large meal after 6:30 pm [22]. Most adults consume less than $10 \mathrm{~g}$ of protein at breakfast $[23,24]$ (Figure 1). In children and young adults, uneven meal distribution of protein appears not to adversely affect growth. The anabolic drive maintains high efficiency of protein use for nitrogen retention even when daily protein is consumed as a single large meal. However in older adults, the quantity and quality of protein at individual meals is important. Adults require a minimum of $15 \mathrm{~g}$ of EAA or at least $30 \mathrm{~g}$ of total protein to fully stimulate skeletal muscle protein synthesis [21,25]. This response appears to be determined by the EAA leucine which serves as a critical signal for triggering initiation of

\section{A. Optimal Protein Distribution}

B. Skewed Protein Distribution

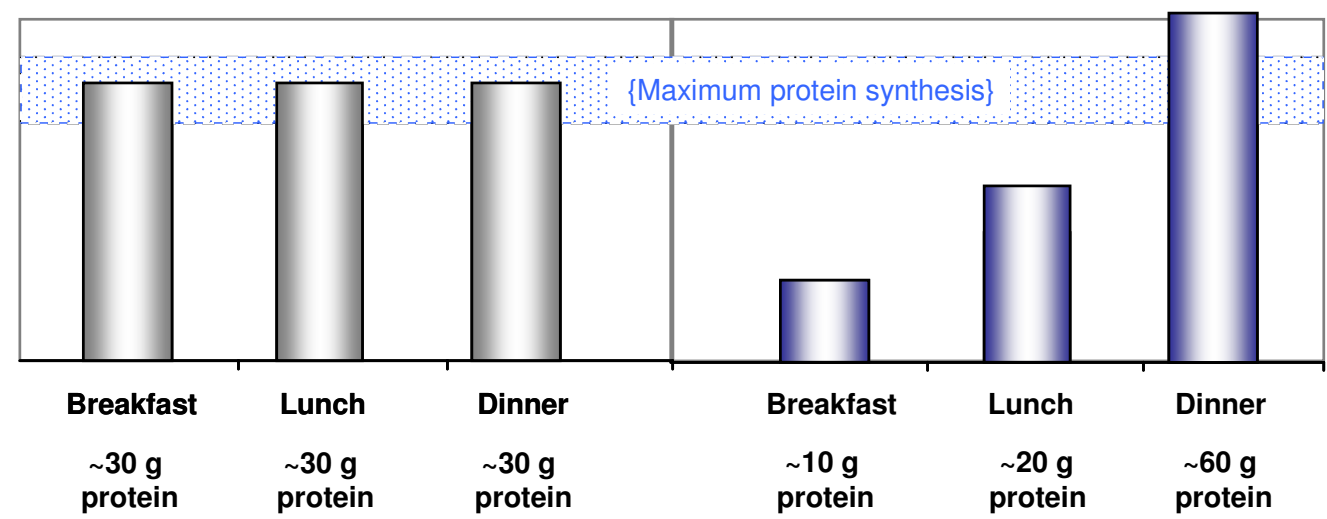

Figure I

Protein distribution at meals. A) Ingestion of 90 grams of protein, distributed evenly at 3 meals. B) Ingestion of 90 grams of proteins unevenly distributed throughout the day. Stimulating muscle protein synthesis to a maximal extent during the meals shown in Figure IA is more likely to provide a greater 24 hour protein anabolic response than the unequal protein distribution in Figure IB. (Adapted from Paddon-Jones \& Rassmussen Curr Opin Clin Nutr Metab Care 2009, 12: 86-90.) 
muscle protein synthesis. Leucine has been well characterized as a unique regulator of the insulin-mTOR signal pathway controlling synthesis of muscle proteins $[7,8]$. In children and young adults, this signal pathway is regulated by insulin and dietary energy while leucine regulates the pathway in adults [26]. Current dietary patterns that provide adequate protein or leucine at only one meal produce an anabolic response only after that meal (Figure 1). This is a critical factor for protection of lean tissues during weight loss or to prevent age-related sarcopenia and osteoporosis.

The meal content of protein is also a key factor for satiety and appetite regulation $[9,10]$. Protein has greater satiety value than either carbohydrates or fats and reduces food intake at subsequent meals [27]. Studies of energy regulation for weight management show that replacing carbohydrates with protein reduces daily energy intake by 200 kcal [9]. The mechanism for this satiety effect may be mediated by intestinal hormones or by reducing peak post-prandial insulin response. While the mechanism remains to be elucidated, it is clear that the improved satiety response requires $>30 \mathrm{~g}$ of protein at a meal and that breakfast has the greatest impact on total daily energy intake [27]. As with protein turnover in muscle and bone, limiting protein intake to a single large meal late in the day reduces the satiety benefits of dietary protein [22].

The most unequivocal evidence for the benefit of increased dietary protein is derived from studies of weight management $[1,28,29]$. Diets with increased protein have been shown to be highly beneficial during weight loss because of their ability to correct body composition and increase satiety and thermogenesis. Higher protein diets increase loss of body weight and body fat and attenuate loss of lean tissue when compared with commonly recommended high carbohydrate low fat low protein diets $[28,30]$. Clearly, the major factors accounting for weight loss are the magnitude of energy restriction and individual compliance. Any diet can produce weight loss. However, long-term success with weight loss relates to maintenance of metabolically active lean tissues and research has proven that higher protein diets protect muscle and bone during weight loss. Use of conventional high carbohydrate, low fat, low protein diets results in $30 \%$ to $40 \%$ loss of lean tissue mass. Use of higher protein diets reduces lean tissue loss to $<15 \%$ and when combined with exercise can halt loss of lean tissue during weight loss [30-32]. Studies also show that moderate protein diets have better long-term compliance.

The effects of protein for maintaining lean tissues appear to translate into health benefits during aging where progressive loss of structural strength and mobility are critical factors. Osteoporosis and sarcopenia have emerged as major issues during aging [2,3]. Prevention of osteoporo- sis is associated with physical activity and dietary calcium and protein [3]. The efficacy of calcium and protein are interrelated [3]. Calcium supplements are largely ineffective for remodeling of bone matrix if protein is limiting. Positive effects of calcium appear to require intakes of protein $>1.2 \mathrm{~g} / \mathrm{kg}$ to have beneficial effects. The long-held belief that increased dietary protein could cause bone loss as reflected in increase urinary calcium is incorrect [33] and protein is now recognized to increase intestinal calcium absorption in addition to enhancing bone matrix turnover [34].

Similar results have been observed with studies of muscle health in elderly where the efficiency of EAA use is reduced $[16,17]$. The level of EAA required to stimulate muscle protein synthesis is increased in part due to reduced anabolic stimulus of hormones. Here again it is important to distinguish the difference between outcome measures of muscle protein metabolism versus nitrogen balance. Long-term prospective outcomes with protein supplementation and muscle function are not available. However cross-sectional studies support the idea that elderly in higher percentiles of protein intake have less agerelated decline in lean tissue mass [35].

Emerging health concerns relate to macronutrient choices for T2DM and MetS [4]. These conditions are characterized by dysregulation of glucose metabolism and have raised new questions about the quantity and quality of carbohydrates in the diet. Extensive research about types of carbohydrates and glycemic index have emerged but evidence is convincing that reduction in total dietary carbohydrates to less than $40 \%$ of total energy is the most effective way to improve glycemic regulations in T2DM and MetS [4].

Early research with MetS evaluated reducing dietary carbohydrates with fats [36]. While increasing dietary fats improved glycemic control and reduced cardiovascular disease (CVD) risk, the prospect of increasing dietary fat remains controversial. Replacement of carbohydrates with protein improves glycemic control measured as reduced post-prandial hyperinsulinemia [37] and in T2DM corrects hyperglycemia and HbA1c [13]. Equally important, reduced carbohydrate diets have decreased TAG, increased HDL and increased LDL particle size (i.e. LDL-C/ApoB) improving the dyslipidemia commonly associated with T2DM and MetS [4]. These conditions are 4-times more important for heart disease and all cause mortality than elevated cholesterol or LDL concentration [38].

\section{New understandings about protein for the Dietary Guidelines \\ - Protein is a critical part of the adult diet}

Protein should be a central part of a complete diet for adults. While physical growth occurs only for a brief 
period of life, the need to repair and remodel muscle and bone continues throughout life. Maintaining the health of muscle and bone is an essential part of the aging process and critical to maintain mobility, health and the active tissues of our body. Protein needs become more important during periods of reduced food intake such as weight loss or during periods of recovery after illness or during aging.

\section{- Protein needs are proportional to body weight; NOT energy intake}

Protein needs for adults relate to body weight. Dietary protein need is often presented as a percentage of energy intake. The DRIs represent the acceptable protein range as $10 \%$ to $35 \%$ of total energy. However, protein needs are constant across all energy intakes. So at low energy intakes, protein needs to be a higher percentage of total calories and at high energy intakes protein can be reduced as a percentage of total calories. In general, dietary protein should be established first in any diet in proportion to body weight and then carbohydrates and fats added determined by energy needs.

\section{- Optimal adult protein use is a function of intake at individual meals}

Protein is an important part of good nutrition at every meal. Vitamins and minerals can fulfill nutrient needs on a once-per-day basis but for protein the body has no ability to store a daily supply. To maintain healthy muscles and bones for adults, at least $30 \mathrm{~g}$ of protein should be consumed at more than one meal. Breakfast is an important meal for dietary protein because the body is in a catabolic state after an overnight fast. A meal with at least 30 $\mathrm{g}$ of protein is required to initiate repletion of body proteins. Protein at breakfast is also critical for regulation of appetite and daily food intake.

\section{- Most adults benefit from protein intakes above the minimum RDA}

Aging populations confront increasing incidence of obesity, osteoporosis, type 2 diabetes, Metabolic Syndrome, heart disease, and sarcopenia which have raised new questions about dietary ratios of carbohydrates, fats, and protein for life-long health. The RDA represents the minimum daily intake for active healthy adults. For most adults, replacing some dietary carbohydrates with protein will help to maintain body composition and mobility, improve blood lipids and lipoproteins, and help to control food intake.

\section{Competing interests}

DKL has received honorarium for participation in speaker bureaus for the National Dairy Council (NDC) and National Cattlemen's Beef Association (NCBA), serves on the Research Advisory Board for the Egg Nutrition Center (ENC), and has research funding from NDC and ENC.

\section{References}

I. Paddon-Jones D, Westman E, Mattes RD, Wolfe RR, Astrup A, Westerterp-Plantenga $M$ : Protein, weight management, and satiety. Am J Clin Nutr 2008, 87: I558S-I56IS.

2. Paddon-Jones D, Short KR, Campbell WW, Volpi E, Wolfe RR: Role of dietary protein in the sarcopenia of aging. Am J Clin Nutr 2008, 87: 1562S-I566S.

3. Heaney RP, Layman DK: Amount and type of protein influences bone health. Am J Clin Nutr 2008, 87: I 567S-I 570S.

4. Layman DK, Clifton P, Gannon MC, Krauss RM, Nuttall FQ: Protein in optimal health: heart disease and type 2 diabetes. Am J Clin Nutr 2008, 87: I57IS-I575S.

5. Munro HN, Crim MC: The protein and amino acids. Modern Nutrition in Health and Disease 7th edition. 1988: I-37.

6. Wolfe RR: The underappreciated role of muscle in health and disease. Am J Clin Nutr 2006, 84:475-482.

7. Kimball SR, Jefferson LS: Regulation of protein synthesis by branched-chain amino acids. Curr Opin Clin Nutr Metab Care 2001, 4:39-43.

8. Layman DK: The role of leucine in weight loss diets and glucose homeostasis. J Nutr 2003, I 33:26IS-267S.

9. Schoeller DA, Buchholz AC: Energetics of obesity and weight control: does diet composition matter? J Am Diet Assoc 2005, 1 05:S24-S28.

10. Weigle DS, Breen PA, Matthys CC, Callahan HS, Meeuws KE, Burden VR, et al:: A high-protein diet induces sustained reductions in appetite, ad libitum caloric intake, and body weight despite compensatory changes in diurnal plasma leptin and ghrelin concentrations. Am J Clin Nutr 2005, 82:4I-48.

II. Westerterp-Plantenga MS, Rolland V, Wilson SAJ, Westerterp KR: Satiety related to $24-\mathrm{h}$ diet-induced thermogenesis during high protein/carbohydrate vs high fat diets measured in a respiratory chamber. Eur J Clin Nutr 1999, 53:495-502.

12. Layman DK, Baum JI: Dietary protein impact on glycemic control during weight loss. J Nutr 2004, I34:968S-973S.

13. Gannon MC, Nuttall FQ, Saeed A, Jordan K, Hoover H: An increase in dietary protein improves the blood glucose response in persons with type 2 diabetes. Am J Clin Nutr 2003, 78:734-4I.

14. Institute of Medicine, Food and Nutrition Board: Dietary Reference Intakes for Energy, Carbohydrate, Fiber, Fat, Fatty Acids, Cholesterol, Protein and Amino Acids. Washington DC: National Academy Press; 2002.

15. Millward DJ: Macronutrient intakes as determinants of dietary protein and amino acid adequacy. J Nutr 2004, I34:I588S-I596S.

16. Volpi E, Sheffield-Moore M, Rasmussen BB, Wolfe RR: Basal muscle amino acid kinetics and protein synthesis in healthy young and older men. JAMA 200I, 286:1206-1212.

17. Volpi E, Mittendorfer B, Rasmussen BB, Wolfe RR: The response of muscle protein anabolism to combined hyperaminoacidemia and glucose-induced hyperinsulinemia is impaired in the elderly. J Clin Endocrinol Metab 2000, 85:4481-4490.

18. Millward DJ, Rivers JPW: The need for indispensable amino acids: the concept of the anabolic drive. Diabetes Metab Rev 1989, 5(2): $191-212$.

19. Fujita S, Rasmussen BB, Cadenas JG, Drummond MJ, Glynn EL, Sattler FR, Volpi E: Aerobic exercise overcomes the age-related insulin resistance of muscle protein metabolism by improving endothelial function and Akt/mTOR signaling. Diabetes 2007, 56:1615-1622.

20. Arnal MA, Mosoni L, Boirie Y, Houlier ML, Morin L, Verdier E, Ritz P, Antoine JM, Prugnaud J, Beaufrere B, Mirand PP: Protein pulse feeding improves protein retention in elderly women. $A m \mathrm{~J}$ Clin Nutr 1999, 69: 1202-1208.

21. Paddon-Jones D, Rasmussen BB: Dietary protein recommendations and the prevention of sarcopenia. Curr Opin Clin Nutr Metab Care 2009, I 2:86-90.

22. de Castro JM: The time of day of food intake influences overall intake in humans. J Nutr 2004, I 34: 104- III.

23. USDA/NHANES: [http://www.ars.usda.gov/SP2UserFiles/Place/ 12355000/pdf/Table I BIA.pdf].

24. USDA/NHANES: [http://www.ars.usda.gov/SP2UserFiles/Place/ 12355000/pdf/Table 9 BIA.pdf].

25. Rasmussen BB, Tipton KD, Miller SL, Wolf SE, Wolfe RR: An oral essential amino acid-carbohydrate supplement enhances 
muscle protein anabolism after resistance exercise. J Appl Physiol 2000, 88:386-392.

26. Garlick PJ: The role of leucine in the regulation of protein metabolism. I Nutr 2005, 135: I553S-I556S.

27. Rolls BJ, Hetherington M, Burley VJ: The specificity of satiety: The influence of foods of different macronutrient content on the development of satiety. Physiol Behav 1988, 43:| 145-I53.

28. Krieger JW, Sitren HS, Daniels MJ, Langkamp-Henken B: Effects of variation in protein and carbohydrate intake on body mass and composition during energy restriction: a meta-regression. Am J Clin Nutr 2006, 83:260-274.

29. Layman DK, Walker DA: Protein importance of leucine in treatment of obesity and the metabolic syndrome. J Nutr 2006, 136:319S-323S.

30. Layman DK, Evans EM, Erickson D, Seyler J, Weber J, Bagshaw D, Griel A, Psota T, Kris-Etherton P: A moderate-protein diet produces sustained weight loss and long-term changes in body composition and blood lipids in obese adults. I Nutr 2009, 139:5|4-2|.

31. Layman DK, Boileau RA, Erickson DJ, Painter JE, Shiue H, Sather C, Christou DD: A reduced ratio of dietary carbohydrate to protein improves body composition and blood lipid profiles during weight loss in adult women. J Nutr 2003, I33:4 I I-4I7.

32. Layman DK, Evans E, Baum JI, Seyler J, Erickson DJ, Boileau RA: Dietary protein and exercise have additive effects on body composition during weight loss in adult women. J Nutr 2005 135:1903-1910.

33. Margen S, Chu J, Kaufmann N, Calloway D: Studies in calcium metabolism. I. The calciuretic effect of dietary protein. Am J Clin Nutr 1974, 27:584-9.

34. Kerstetter J, O'Brien K, Insogna K: Dietary protein affects intestinal calcium absorption. Am J Clin Nutr 1998, 68:859-65.

35. Houston DK, Nicklas BJ, Ding J, Harris TB, Tylavsky FA, Newman AB, Lee JS, Sahyoun NR, Visser M, Kritchevsky SB: Dietary protein intake is associated with lean mass change in older, community-dwelling adults: the Health, Aging, and Body Composition (Health ABC) Study. Am J Clin Nutr 2008, 87: I $150-155$

36. Reaven GM: The metabolic syndrome: is this diagnosis necessary? Am J Clin Nutr 2006, 83: I 237-47.

37. Walker-Lasker DA, Evans EM, Layman DK: Moderate carbohydrate, moderate protein weight loss diet reduces cardiovascular disease risk compared to high carbohydrate, low protein diet in obese adults: A randomized clinical trial. Nutr \& Metab 2008, 5:30-39.

38. Isomaa B, Almgren $P$, Tuomi T, Forsen B, Lahti K, Nissen M, Taskinen MR, Groop L: Cardiovascular morbidity and mortality associated with the metabolic syndrome. Diabetes Care 200I, 24:683-689.
Publish with Biomed Central and every scientist can read your work free of charge

"BioMed Central will be the most significant development for disseminating the results of biomedical research in our lifetime. "

Sir Paul Nurse, Cancer Research UK

Your research papers will be:

- available free of charge to the entire biomedical community

- peer reviewed and published immediately upon acceptance

- cited in PubMed and archived on PubMed Central

- yours - you keep the copyright
BioMedcentral 